\title{
Evaluasi Penularan Filariasis Limfatik di Provinsi Riau dan Bangka Belitung: Parasit pada Manusia dan Reservoir
}

\section{Evaluation of Lymphatic Filariasis Transmission in Riau and Bangka Belitung Province: Parasite Infection on Human and Vector}

\author{
Santoso $^{1 * \mathscr{\ell}}$, Yahya ${ }^{1 \mathscr{\ell}}$, Lasbudi Pertama Ambarita ${ }^{1 \mathscr{\ell}}$, Anif Budiyanto ${ }^{1}$, Nungki Hapsari \\ Suryaningtyas ${ }^{1}$, I Gede Wempi DSP ${ }^{1}$, Yanelza Supranelfy ${ }^{1}$, Tanwirotun Ni'mah ${ }^{1}$, Anorital ${ }^{2}$, Rita \\ Marleta $^{2}$ \\ ${ }^{1}$ Balai Penelitian dan Pengembangan Kesehatan Baturaja \\ Jalan A. Yani KM 7, Kemelak, Baturaja, Sumatera Selatan, Indonesia \\ ${ }^{2}$ Badan Penelitian dan Pengembangan Kesehatan Kementerian Kesehatan \\ Jalan Percetakan Negara No 29, Jakarta, Indonesia \\ *E_mail: santosobaturaja@gmail.com \\ Kontributor Utama
}

Received date: 05-04-2019, Revised date: 29-07-2019, Accepted date: 11-10-2019

\begin{abstract}
ABSTRAK
Pengobatan massal dan survei evaluasi penularan filariasis merupakan strategi dalam pengendalian limfatik filariasis. Surveilans periode stop Pemberian Obat Pencegahan Massal (POPM) perlu dilakukan setahun sekali selama 5 tahun sebelum mendapatkan sertifikat eliminasi filariasis. Tujuan penelitian ini untuk menentukan status eliminasi filariasis di daerah yang telah melakukan pengobatan massal selama 5 tahun selama bulan Juli-November 2017, telah dilakukan pengambilan darah jari penduduk berusia 5 tahun ke atas dan pemeriksaan terhadap hewan reservoir di Provinsi Riau dan Bangka Belitung. Hasil studi mendapatkan bahwa $M f$ rate di Kabupaten Kuatan Singingi dan Pelalawan di Provinsi Riau adalah $<1 \%$, sedangkan Mf rate di Kabupaten Bangka Barat dan Belitung adalah $>1 \%$ dengan spesies Brugia malayi. Prevalensi kecacingan hasil pemeriksaan feses di Kabupaten Kuantan Singingi sebesar 13,6\%; Pelalawan 2,4\%; Bangka Barat 5,3\%; dan Belitung 11,5\%. Hewan reservoir positif $B$. malayi yaitu 2 ekor kucing (Felis cattus); 1 ekor anjìng (Canis familiaris), dan 1 ekor monyet ekor panjang (Macaca fascicularis). Provinsi Riau sudah tidak menjadi daerah endemis filariasis ( $\mathrm{f} f \mathrm{rate}<1 \%$ ), sedangkan Provinsi Bangka Belitung Mf rate masih $>1 \%$. Risiko penularan di Kabupaten Kuantan Singingi sudah rendah, sedangkan di Kabupaten Pelalawan, Bangka Barat, dan Belitung masih tinggi.
\end{abstract}

Kata kunci: Riau, Bangka Belitung, limfatik filariasis, reservoir, evaluasi

\section{ABSTRACT}

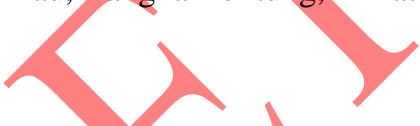

Mass treatment and evaluation surveys of filariasis transmission were strategies in the control of lymphatic filariasis. Mass Drug Administration (MDA) stop period surveillance is required for five years before obtaining a lymphatic filariasis elimination certificate. The aim of conducting the study was to evaluate the activities of lymphatic filariasis elimination in areas that have been doing MDA for five years. During July-November 2017, fingertip blood samples of people aged five years and examination of reservoir animals was done in Riau and Bangka Belitung Province. The results of the study found that in Kuatan Singingi and Pelalawan district Mf rate was $<1 \%$, in West Bangka and Belitung districts Mf rate> $1 \%$ with all specied identified as Brugia malayi. Survey of animal reservoir obtained positive of $\mathrm{B}$. malayi on two cats (Felis cattus), one dog (Canis familiaris), and one monkey (Macaca fascicularis). Riau Province was not a filariasis endemic area (Mf rate <1\%), while Bangka Belitung Province Mf rate was still >1\%. The risk of transmission in Kuantan Singingi District was already low, while in Pelalawan regency, West Bangka and Belitung were still high.

Keywords: Riau, Bangka Belitung, lymphatic filariasis, reservoir, evaluation

\section{PENDAHULUAN}

Limfatik filariasis masih menjadi masalah kesehatan di Indonesia. Sampai akhir tahun 2016, dari 514 kabupaten/kota di Indonesia dilaporkan 236 kabupaten/kota endemis filariasis. Dari 236 kabupaten/kota 
yang endemis filariasis tersebut, 51 kabupaten/kota telah melakukan Pemberian Obat Pencegahan Massal filariasis (POPM) setahun sekali selama 5 tahun berturut-turut (5 putaran), 8 kabupaten telah mendapat sertifikat eliminasi dan 43 kabupaten dalam tahap Transmission Assessment Survey (TAS). ${ }^{1}$

Kabupaten Kuantan Singigi Provinsi Riau dinyatakan endemis filariasis sejak tahun 2003 berdasarkan hasil Survei Darah Jari (SDJ) di Desa Pulau Bayur dengan Microfilaria rate (Mf rate) sebesar 17\% dengan jumlah kasus kronis sebanyak 20 kasus. Kegiatan POPM filariasis di Kabupaten Kuantan Singingi mulai dilakukan sejak tahun 2011. Pengendalian filariasis di Kabupaten Pelalawan Provinsi Riau dimulai pada tahun 2007 dengan dilakukannya kegiatan pemeriksaan darah jari di delapan desa, diperoleh angka mikrofilaria sebesar 1,3\%. Kegiatan SDJ dilanjutkan pada tahun 2010 dan 2012. Kegiatan POPM pertama kali dilakukan pada tahun 2008, dan kegiatan POPM terakhir dilakukan pada tahun 2012. Jumlah penderita kronis filariasis di Kabupaten Bangka Barat hingga tahun 2016 sebanyak 30 orang yang tersebar di 5 kecamatan. Jumlah seluruh kasus klinis filariasis di Kabupaten Belitung hingga tahun 2017 ada sebanyak 30 kasus, yang seluruhnya merupakan kasus lama. Kegiatan pengobatan massal filariasis di Kabupaten Belitung dimulai sejak tahun 2006 hingga terakhir tahun $2010 .^{2}$

Filariasis yang disebabkan Brugia malayi termasuk dalam jenis penyakit zoonotik, sehingga perlu dilakukan pemeriksaan darah terhadap hewan yang berperan sebagai hewan reservoir diantaranya; anjing (Canis familiaris), kucing (Felis cattus), monyet (Macaca fascicularis), dan lutung (Presbytis cristata). ${ }^{3,4}$ Berdasarkan hal tersebut, maka kegiatan pengendalian filariasis selain dilakukan terhadap manusia sebagai sumber infeksi primer juga dilakukan pengendalian terhadap hewan reservoir, sehingga penularan filariasis di daerah endemis dapat dihentikan.

Tujuan utama dari penelitian ini adalah untuk menilai status eliminasi filariasis di antara orang Riau dan Bangka Belitung serta infeksi pada hewan reservoir, setelah program eliminasi filariasis limfatik, di mana POPM filariasis telah berlangsung selama 5 tahun melalui pengobatan massal.

\section{METODE}

\section{Area Penelitian}

Penelitian dilakukan di 2 provinsi, yaitu Provinsi Riau dan Bangka Belitung. Masingmasing provinsi dipilih 2 kabupaten yang telah selesai melakukan Mass Drug Administration (MDA), selanjutnya dari masing-masing kabupaten dipilih 2 desa dengan endemisitas tertinggi, sehingga jumlah area penelitian adalah 8 desa. Penelitian ini merupakan bagian penelitian studi multicenter filariasis tahun 2017 di 23 kabupaten endemis filariasis di Indonesia. ${ }^{5}$ Balai Litbangkes Baturaja bertanggungjawab terhađap 4 lokasi baik dalam hal anggaran maupun petugas pelaksana penelitian sehingga analisis dapat dilakukan terpisah. Hasil penelitian juga mendapatkan hal yang berbeda dengan lokasi lainnya karena ditemukan mikrofilaria B. malayi pada hewan reservoir. Lokasi penelitian di Provinsi Riau adalah Kabupaten Kuantan Singingi (Desa Pulau Panjang Cerenti dan Sukadamai) dan Kabupaten Pelalawan (Desa Ukui 1 dan Sialang Bungkuk). Kabupaten terpilih di Provinsi Bangka Belitung adalah Kabupaten Bangka Barat (Desa Air Gantang dan Tanjung Niur) dan Belitung (Desa Cerucuk dan Kembiri).

\section{Persetujuan Etik Penelitian}

Izin penelitian diperoleh dari Komisi Etik Penelitian Kesehatan Badan Penelitian dan Pengembangan Kesehatan Nomor: LB.02.01/2/KE.167/2017 tanggal 4 Mei 2017. Penduduk diberi penjelasan tentang latar belakang/alasan, tujuan, prosedur/pelaksanaan penelitian, manfaat dan risiko keterlibatan dalam penelitian. Partisipasi penduduk dalam penelitian adalah sukarela.

\section{Pemeriksaan Klinik}

Pemeriksaan klinik dilakukan oleh dokter yang terlatih dengan sasaran penduduk yang diperiksa adalah penduduk yang tinggal di 
sekitar rumah penderita elefantiasis. Pemeriksaan dilakukan di balai desa di dalam ruangan yang tertutup. Penduduk yang diperiksa adalah penduduk yang berusia lebih dari 5 tahun. Penduduk yang diperiksa adalah seluruh penduduk yang akan diperiksa darahnya, yaitu sebesar 310 orang per desa sesuai dengan perhitungan besar sampel minimal.

\section{Pemeriksaan Parasit Darah Manusia}

Pengambilan darah dilakukan di balai desa oleh petugas analis yang terlatih. Pengambilan darah pada penduduk dilakukan pada jam 22.00-02.00. . Darah diambil dari ujung jari tangan dengan volume $60 \mu$ l dengan menggunakan pipet kapiler non heparin dan dibuat sediaan darah tebal dalam bentuk 3 garis dengan volume masing-masing 20 $\mu 1$. Apusan darah pada slide diwarnai dengan larutan giemsa 3\% selama 30 menit dan dikeringkan. ${ }^{4}$ Slide diperiksa dengan mikroskop di Laboratorium Parasitologi Balai Litbangkes oleh analis yang terlatih dengan menggunakan perbesaran 10x10 untuk menemukan mikrofilaria, dan perbesaran 10x40 untuk menentukan spesies mikrofilaria. Spesies mikrofilaria diidentifikasi berdasarkan fitur dan ukuran morfologi tertentu berdasarkan kunci identifikasi mikrofilaria dengan mikroskop binokuler. $^{6}$

\section{Pemeriksaan Darah Hewan Reservoir}

Hewan reservoir untuk kucing dan anjing yang diperiksa adalah hewan yang dipelihara oleh penduduk di lokasi penelitian. Sedangkan untuk monyet ekor panjang yang diperiksa adalah monyet peliharaan penduduk dan monyet liar yang berada di sekitar perumahan penduduk.

Pemasangan perangkap monyet dilakukan di kebun sekitar rumah penduduk. Monyet yang terperangkap dimasukkan dalam kandang untuk diambil darahnya pada malam hari oleh dokter hewan yang terlatih. Kucing dan anjing yang diperiksa adalah yang merupakan peliharaan penduduk. Sebelum diambil darahnya, hewan tersebut dibius terlebih dahulu. Pengambilan darah dilakukan pada vena savena (kucing/anjing) atau vena femoralis (monyet) sebanyak $1 \mathrm{cc}$. Sebanyak $60 \mu 1$ darah diteteskan pada slide dan dibuat sediaan darah tebal untuk pemeriksaan mikroskopis, sedangkan sisanya diteteskan pada kertas whatman untuk pemeriksaan Polymerase Chain Reaction (PCR) dilakukan di Laboratorium Puslitbang Biomedis dan Teknologi Dasar Kesehatan.

\section{HASIL}

\section{Pemeriksaan Klinik}

Hasil pemeriksaan klinik menunjukkan bahwa gejala klinik yang paling banyak ditemukan adalah demam filaria. Pemeriksaan klinik di Kabupaten Pelalawan tidak mendapatkan adanya penduduk yang mengalami gejala/klinikfilariasis. Seluruh gejala klinik filariasis ditemukan, sedangkan di Kabupaten Belitung hampir semua gejala klinikditemukan kecuali hydrocele. Jumlah responden yang mengalami gejala klinik seluruhnya adalah 111 (3\%). Gejala klinik yang ditemui meliputi demam filaria (57 kasus), elefantiasis (7 kasus), retrograde limphangitis (20 kasus), limfadenitis (13 kasus), early lymphodema (6 kasus), abses (3 kasus), elefantiasis (4 kasus), dan hydrocele (1 kasus).

\section{Pemeriksaan Mikrofilaria Darah}

Hasil pemeriksaan darah jari pada penduduk di 8 desa terpilih mendapatkan sebanyak 13 penduduk positif mikrofilaria $B$. malayi dari 1.501 penduduk yang diperiksa. Jumlah penduduk positif paling banyak ditemukan di 3 desa, yaitu Desa Tanjung Niur (Bangka), Cerucuk dan Kembiri (Belitung) (Tabel 1).

Kepadatan mikrofilaria per orang berkisar antara 1-43 ekor mikrofilaria per $60 \mu \mathrm{L}$. Kepadatan mikrofilaria tertinggi ditemukan pada penduduk laki-laki usia 60 tahun di wilayah Kabupaten Bangka (Tabel 2). 


\section{Pemeriksaan Darah Hewan Reservoir}

Spesies cacing filaria yang ditemukan pada hewan reservoir adalah $B$. malayi, $B$. pahangi, dan Dirofilaria. Cacing B. malayi ditemukan pada kucing, anjing, dan monyet ekor panjang. Jumlah hewan yang positif $B$. malayi sebanyak 4 ekor yang ditemukan pada 2 ekor kucing dan 1 ekor anjing di Kabupaten Pelalawan dan 1 ekor monyet ekor panjang di
Kabupaten Belitung. Mikrofilaria B. pahangi hanya ditemukan pada 1 ekor anjing di Kabupaten Pelalawan. Spesies Dirofilaria ditemukan pada 11 ekor hewan, 1 ekor kucing, dan 5 ekor anjing di Kabupaten Kuantan Singingi, 3 ekor kucing di Kabupaten Bangka Barat, dan 2 ekor monyet ekor panjang di Kabupaten Belitung.

Tabel 1. Distribusi Hasil Pemeriksaan Mikroskopik Berdasarkan Kabupaten dan Desa

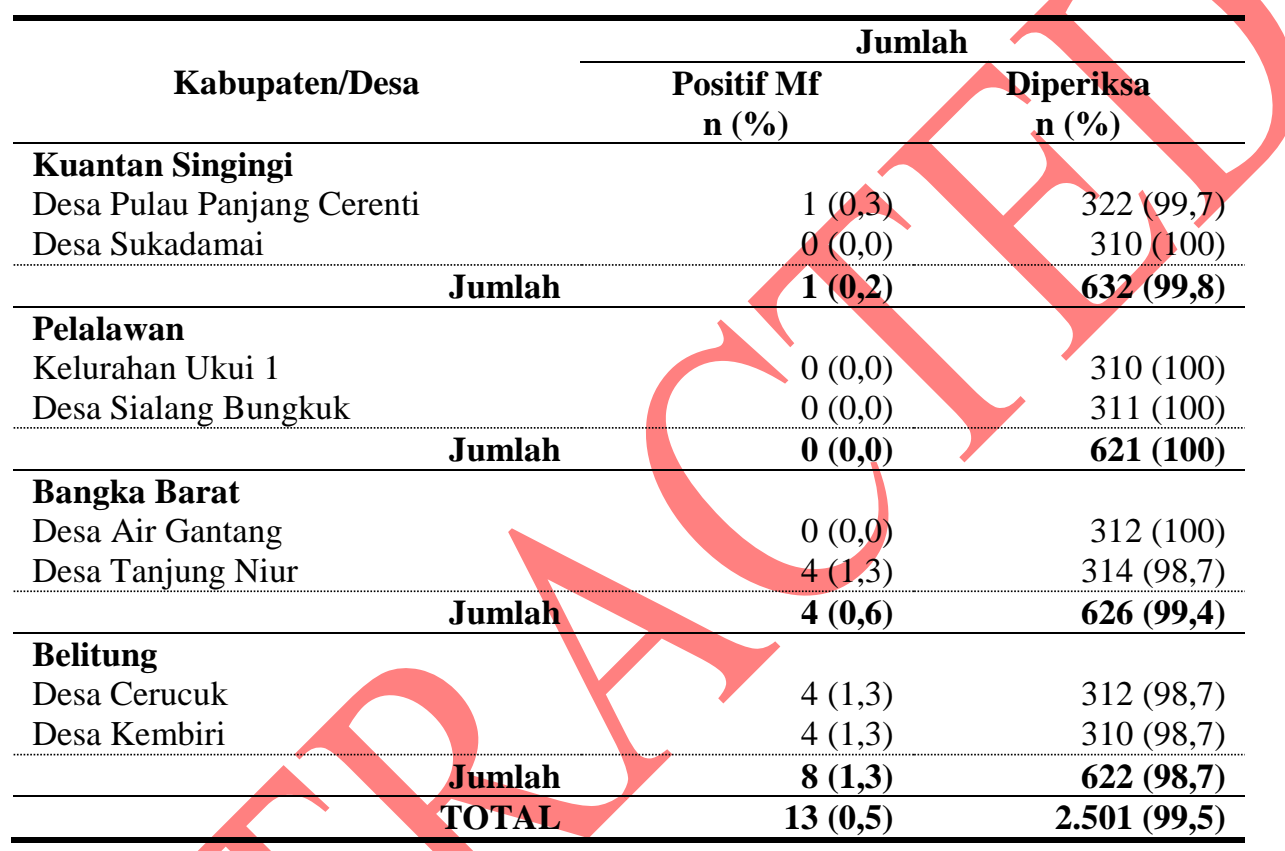

Tabel 2. Distribusi Responden Positif Mikrofilaria Berdasarkan Kabupaten

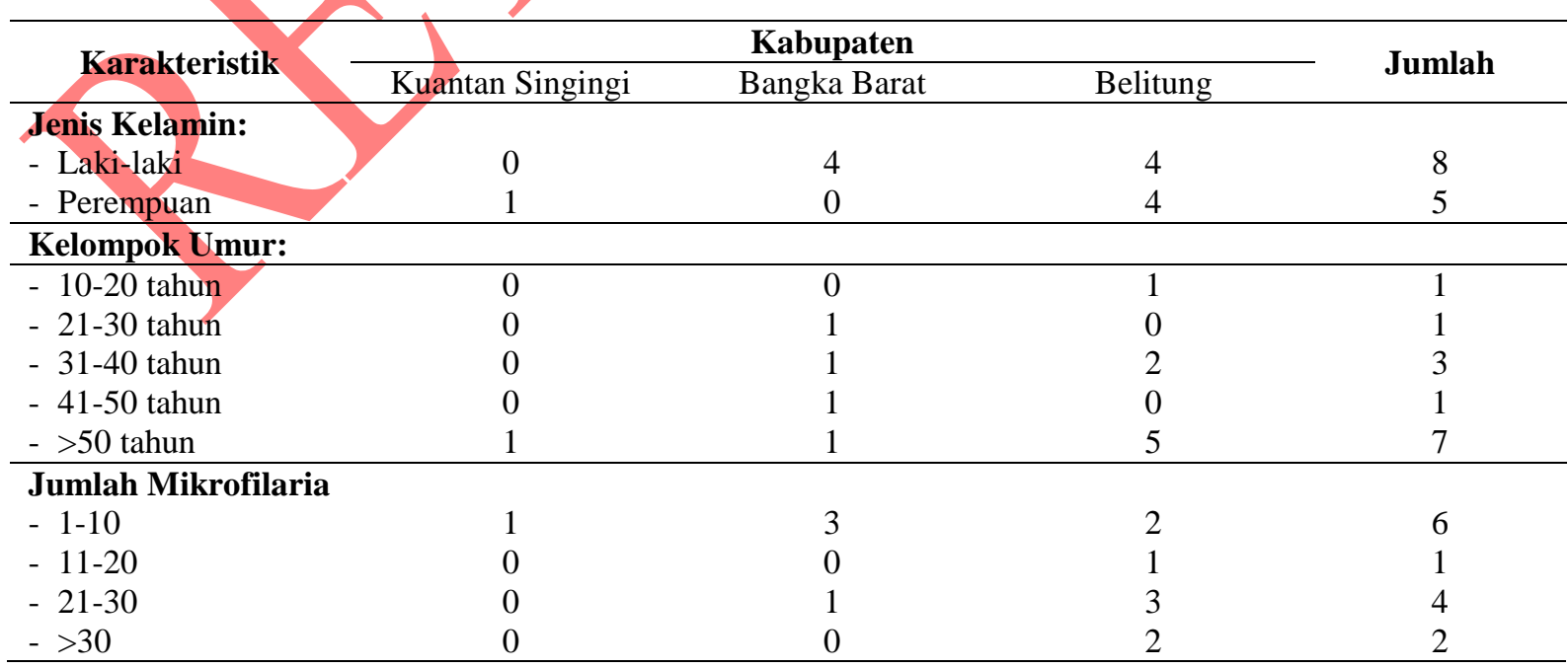




\section{PEMBAHASAN}

Hasil pemeriksaan klinik terhadap responden sebelum dilakukan pengambilan darah pada malam hari menunjukkan adanya responden yang memiliki gejala klinik filariasis berupa demam filaria dan limfadenitis. Kedua gejala tersebut merupakan gejala awal penderita filariasis. ${ }^{4}$ Meskipun gejala demam filaria sulit dibedakan dengan gejala demam penyakit lain, namun dengan adanya gejala khas filariasis berupa demam berulang selama tiga hari atau dengan frekuensi tiga kali dalam sebulan atau lebih, hal ini perlu diwaspadai, mengingat jumlah responden yang mengalami gejala tersebut cukup banyak. Hal ini berkaitan juga dengan gejala klinis malaria yang mirip dengan gejala awal filariasis, mengingat di lokasi penelitian juga merupakan daerah endemis malaria. ${ }^{7,8}$ Berdasarkan hasil pemeriksaan darah jari, hanya satu responden yang positif mikrofilaria dari 36 responden yang mengalami demam berulang. Responden yang lain kemungkinan bukan mengalami gejala demam filaria, melainkan demam karena penyakit lain, salah satunya demam karena malaria. Kemungkinan lain responden tersebut sebenarnya menderita filariasis, namun karena kepadatan mikrofilaria yang rendah sehingga tidak ditemukan mikrofilaria pada saat pemeriksaan darah. Hal lain yang juga mungkin terjadi karena sifat mikrofilaria $B$. malayi yang bersifat sub periodik nokturnal dengan puncak kepadatan pada jam tertentu, sehingga hal ini berhubungan dengan waktu pengambilan darahnya. Puncak kepadatan parasit di Kabupaten Batanghari terjadi pada pukul 01.00 WIB sedangkan di Kabupaten Ogan Komering Ulu Timur pada pukul 21.00 WIB. ${ }^{9,10}$ Hasil penelitian di Kabupaten Tabalong filariasis $B$. malayi menunjukkan periodisitas non periodik karena munculnya kepadatan mikrofilaria yang tidak menentu. ${ }^{11}$

Episode akut filariasis dari inflamasi lokal pada kulit, kelenjar limfa, dan saluran limfa sering disertai limfodema kronis atau elephantiasis yang lama kelamaan menjadi gejala kronis. Beberapa episode akut tersebut disebabkan oleh respons imun tubuh terhadap parasit, tetapi umumnya merupakan dampak dari kerusakan limfatik. Di daerah endemis, manifestasi akut dan kronik cenderung lebih sering dan cepat pada pengungsi ataupun pendatang dibandingkan penduduk asli. Limfodema dapat terjadi dalam kurun waktu waktu 6 bulan dan elephantiasis paling cepat terjadi 1 tahun setelah kedatangan. ${ }^{12}$

Kabupaten lokasi penelitian merupakan daerah endemis filariasis dengan $M f$ rate $>1 \%$ sebelum POPM filariasis dan setelah POPM filariasis turun menjadi sebesar $<1 \%$. Microfilaria rate di Kabupaten Bangka Barat sebelum POPM sebesar 1,89\% dan setelah POPM turun menjadi 0,4\%, di Kabupaten Belitung sebelum POPM Mf rate sebesar 2,8\% dan setelah POPM 0,1\%, di Kabupaten Pelalawan $M f$ rate sebelum POPM sebesar $1,8 \%$ dan setelah POPM 0\%, sedangkan di Kabupaten Kuantan Singingi sebelum POPM sebesar $17,0 \%$ dan setelah POPM sebesar $0 \%$. Sesuai dengan pedoman Kementerian Kesehatan, maka daerah yang sudah lulus evaluasi penularan filariasis (TAS-1) masih perlu melakukan TAS-2 dan TAS-3 dengan periode waktu dua tahun. Selama periode tersebut, maka Dinas Kesehatan Kabupaten harus melakukan surveilans agar di wilayah tersebut benar-benar tidak terjadi penularan filariasis. $^{4}$

Hasil survei darah jari mendapatkan bahwa di wilayah Provinsi Riau ditemukan $M f$ rate $<1 \%(0,3 \%)$ sedangkan di Provinsi Bangka Belitung menunjukkan prevalensi masih tinggi karena $M$ f rate $>1 \%(1,3 \%)$. Hasil survei darah jari di Kabupaten Bangka menunjukkan perbedaan antara 2 desa yang menjadi lokasi penelitian Desa Tanjung Niur ditemukan 4 penduduk yang positif mikrofilaria atau sebesar 1,3\%, sedangkan Desa Air Gantang seluruh penduduk yang diperiksa dinyatakan negatif. Hasil pemetaan awal endemisitas (baseline survey) sebelum pengobatan di Desa Tanjung Niur sebesar 1,6\%, sedangkan di Desa Air Gantang sebesar 1,89\%. Sementara di Kabupaten Belitung dua desa yang diperiksa menunjukkan angka prevalensi $>1 \%$, yaitu 
sebesar 1,3\%. Hasil penelitian ini mendapatkan bahwa di wilayah Provinsi Bangka Belitung masih endemis filariasis karena $M f$ rate $>1 \%$ yaitu sebesar 1,3\%.

Kabupaten Bangka Barat dan Belitung sudah dinyatakan lulus TAS 1-3, namun dari hasil penelitian ini masih menunjukkan adanya angka prevalensi yang cukup tinggi yaitu 1,3\%. Meskipun kedua kabupaten tersebut sudah dinyatakan bebas filariasis karena sudah mendapat sertifikat eliminasi filariasis dari Kementerian Kesehatan, namun perlu tetap dilakukan surveilans untuk mencegah agar penularan lebih lanjut tidak terjadi. Hasil penelitian yang menemukan adanya kasus baru perlu ditindaklanjuti dengan kegiatan pengobatan selektif terhadap penderita dan keluarganya. Hal ini perlu dilakuikan untuk mencegah penularan lebih lanjut di lokasi penelitian. Kegagalan TAS juga pernah terjadi di Kabupaten Agam, sehingga pengobatan massal harus dilanjutkan selama dua tahun pengobatan dengan pemberian obat sekali per tahun. ${ }^{13}$

Apabila dilihat dari rendahnya cakupan minum obat seperti yang ditampilkan pada aspek perilaku dari hasil wawancara, menunjukkan populasi penduduk di Dusun Pelaik (Desa Tanjung Niur) rentan terhadap penularan filariasis, namun apabila dilihat dari riwayat pengobatan yang telah berakhir pada tahun 2009 dengan cakupan pengobatan dari tahun 2005-2009 berturut-turut sebesar 93,4\%; 90,4\%; $87,1 \%$; $92,1 \%$; dan $91,2 \%$ maka dugaan yang dapat diambil adalah risiko penularan yang masih cukup tinggi terutama karena kehadiran hewan reservoir yang berada di sekitar wilayah dusun maupun di sekitar tempat mencari nafkah penduduk. Kondisi tersebut didukung dengan informasi bahwa keempat responden yang positif filariasis tersebut memiliki pekerjaan berkebun, menambang timah dan seringkali bekerja hingga malam hari. Responden juga tidak selalu minum obat yang diberikan selama 5 tahun pengobatan. Hal ini juga merupakan salah satu faktor risiko terkena filariasis. Tujuan dari POPM sendiri adalah membagikan obat anti filarial dengan kombinasi DEC dan Albendazole kepada seluruh individu sasaran pada wilayah unit implementasi untuk menurunkan prevalensi. ${ }^{14}$ Semakin banyak penduduk mengkonsumsi obat maka akan meningkatkan peluang keberhasilan memutus rantai penularan, sebaliknya makin rendah cakupan pengobatan akan menurunkan probabilitas memutus penularan sehingga konsekuensinya pengobatan lanjutan perlu dilakukan. Jumlah tahun pengobatan yang dibutuhkan untuk menurunkan prevalensi mikrofilaria menjadi kurang dari $1 \%$ bergantung kepada tiga faktor kunci yaitu baseline prevalensi mikrofilaria, kepatuhan minum obat dalam kegiatan POPM, serta efisiensi yektor dan reservoir (termasuk ada tidaknya kegiatan pengendalian vektor). ${ }^{15}$ Di daerah dengan penularan yang intens dan cakupan pengobatan renđah, durasi pengobatan yang lebih lama. Hal ini mungkin perlu dilakukan di Kabupaten Bangka Barat dan Belitung meskipun sudah lulus TAS 1 dan 3, mengingat penelitian sebelumnya. Hasil penelitian sebelumnya di Kabupaten Bangka masih mendapatkan angka prevalensi sebesar 2\% (3/150) meskipun di Kabupaten ini telah lulus TAS-3. ${ }^{16}$

Kepatuhan minum obat merupakan kunci utama dalam pengendalian filariasis. Kepatuhan minum obat sangat didukung oleh adanya pengawas minum obat. Kegiatan POPM hanya dilakukan dengan membagikan obat kepada penduduk tanpa adanya pengawasan sehingga kemungkinan obat yang diberikan tidak diminum oleh penduduk. Hal ini berdasarkan hasil wawancara terhadap penduduk yang mendapatkan obat, namun tidak diminum karena tidak adanya pengawasan minum obat. Sebaliknya tingkat kepatuhan yang rendah akan menghambat program eliminasi filariasis. Hasil penelitian di Banyuasin menunjukkan adanya penurunan angka prevalensi filariasis, sedangkan di Kabupaten Mamuju Utara menunjukkan hal yang sebaliknya. Meskipun terjadi penurunan Mf rate, namun masih $>1 \%$ sehingga dikategorikan sebagai endemis filariasis. Hal ini disebabkan karena rendahnya cakupan 
pengobatan yaitu sebesar 5,5\% tahun 2012, $3,8 \%$ tahun 2013, dan 3,9\% tahun 2013. ${ }^{17-19}$

Hasil pemeriksaan terhadap hewan reservoir di Kabupaten Kuatan Singinngi tidak menemukan adanya DNA cacing B. malayi. Hasil pemeriksaan hanya menemukan cacing Cacing Dirofilaria merupakan cacing yang hidup di dalam tubuh hewan, namun belum ada laporan cacing tersebut menginfeksi manusia. Meskipun tidak ditemukan adanya hewan reservoir yang positif, namun tetap perlu diwaspadai kemungkinan masih ada hewan reservoir lain positif namun tidak tertangkap pada saat penelitian. Hal ini dikarenakan jumlah hewan reservoir yang paling banyak diperiksa adalah kucing, sedangkan monyet ekor panjang yang berhasil ditangkap dan diperiksa hanya dua ekor. Peluang monyet ekor panjang untuk terinfeksi mikrofilaria $B$. malayi sebenarnya cukup tinggi apabila monyet tersebut tinggal di sekitar daerah endemis filariasis B. malayi. Hal ini berkaitan juga dengan keberadaan vektor B. malayi yang dominan (Mansonia spp.) yang memiliki habitat di daerah rawa-rawa. Sementara berdasarkan hasil penelitian sebelumnya jenis hewan reservoir untuk malayi yang paling banyak ditemukan adalah kucing (Felis catus). ${ }^{10,20}$

Hasil pemeriksaan darah kucing rumah (Felis catus) secara mikroskopis dan hasil konfirmasi dengan PCR di Kabupaten Pelalawan mendapatkan 3 ekor kucing positif B. malayi. Hal ini menunjukkan bahwa potensi penularan filariasis di Kabupaten Pelalawan masih ada meskipun hasil SDJ tidak menemukan penduduk yang positif.

Hasil pemeriksaan secara mikroskopis terhadap hewan reservoir di Kabupaten Bangka Barat menunjukkan 6 ekor hewan (3 ekor kucing dan 3 ekor anjing) positif Dirofilariasis sp., dan seluruh hewan tersebut berasal dari Desa Tanjung Niur (Dusun Pelaik). Kondisi lingkungan tempat hewan yang dinyatakan positif Dirofilariasis cukup mendukung karena Dusun Pelaik (Desa Tanjung Niur) dikelilingi oleh perkebunan sawit milik perusahaan swasta maupun kebun milik penduduk. Pengamatan selama penelitian di lapangan kerap dijumpai hewan liar yaitu kera ekor panjang yang berpotensi sebagai hewan reservoir. Selain kera ekor panjang, hewan lainnya yang ditemukan liar dan berkeliaran di sekitar pemukiman penduduk adalah anjing.

Reservoir yang diperiksa di Kabupaten Belitung berjumlah 117 ekor, terdiri dari 84 kucing, 30 monyet ekor panjang, dan 3 anjing. Berdasarkan hasil pemeriksaan mikroskopis sediaan darah reservoir ditemukan 5 hewan terinfeksi oleh cacing filaria dari genus Dirofilaria yaitu 3 ekor monyet ekor panjang (Macaca fascicularis) dan 2 ekor anjing (Canis familiaris). Pada penelitian ini identifikasi parasit dari genus Dirofilaria hanya sampai tingkat genus belum sampai spesies. Hasil pemeriksaan dengan metode PCR menemukan 4 sampel dengan spesies B. malayi pada anjing, kucing, dan monyet ekor panjang di Kabupaten Pelalawan dan Belitưng serta 1 sampel dengan spesies non B. malayi pada kucing di Kabupaten Pelalawan. Pemeriksaan darah pada kucing di Desa Muara Padang Kabupaten Banyuasin menemukan bahwa 11 sampel positif mikrofilaria (Dirofilaria repens) dari 17 sampel yang diperiksa. ${ }^{23}$

Dirofilaria immitis dan $D$. repens merupakan jenis yang paling banyak ditemukan dibandingkan jenis lainnya seperti $D$. tenuis, $D$. ursi, D. subdermata, dan

D. striata.

Dirofilaria immitis adalah golongan parasit nematode filaria yang berbahaya bagi anjing, kucing, dan mamalia lainnya. Cacing ini umumnya menetap di jantung terutama ventrikel kanan dan arteri pulmonalis inang. ${ }^{24}$ Berbeda dengan $D$. repens yang umumnya menempati jaringan subkutan. ${ }^{25}$

Keberadaan D. immitis di jantung dapat menghalangi arteri pulmonalis yang menyebabkan beberapa gejala seperti batuk, kelelahan saat beraktivitas, pingsan, batuk berdarah, dan kehilangan bobot tubuh yang parah. ${ }^{26}$

Prevalensi D. immitis di dunia yang tertinggi di temukan di Pulau Canary dan Madeira serta di negara-negara Mediterania. ${ }^{27}$ Prevalensi dirofilariasis di Indonesia menunjukkan angka berbeda-beda, di 
Kecamatan Lhoknga Aceh Besar prevalensi dirofilariasis pada anjing lokal sebesar 10\%; di wilayah Jawa Barat 4,2\%; dan Jawa Tengah $2 \%$. Faktor yang mempengaruhi penularan $D$. immitis meliputi keberadaan berbagai spesies nyamuk di suatu wilayah, kerapatan populasi nyamuk dan temperatur. Kasus dirofilariasis juga kemungkinan besar terkait dengan kepadatan populasi anjing sebagai reservoir di suatu tempat, ${ }^{24}$ namun peluang hewan untuk menjadi reservoir yang ideal ditentukan tidak hanya oleh jumlah populasi yang terinfeksi, akan tetapi juga kemampuannya untuk survive, kapasitasnya mempertahankan reproduksi parasit dalam jangka waktu yang lama serta adaptasinya terhadap parasit itu sendiri. ${ }^{27}$

Meskipun dirofilariasis pada manusia di Indonesia ini belum menjadi ancaman serius, namun potensinya sebagai penyakit zoonosis yang perlu diwaspadai karena jumlah kasusnya semakin meningkat. Dirofilariasis pada manusia yang telah dilaporkan paling banyak di Eropa sebanyak 4250 kasus. Kasus dirofilariasis di Asia dilaporkan di Sri Lanka sebanyak 135 kasus, 103 kasus di India, dan di Jepang dilaporkan 277 kasus. Kasus dirofilariasis paru-paru di Jepang yang disebabkan $D$. immitis sebanyak 3 kasus. Sebagian besar orang yang menderita pulmonari dirofilariasis tidak menunjukkan gejala sementara sebagian lainnya menunjukkan gejala batuk, batuk berdarah, nyeri dada, demam, dan efusi pleura (cairan berlebih pada jaringan antara paru-paru dan rongga dada). Sementara itu, orang yang terinfeksi D. repens dân $D$. tenui, tanda yang paling nyata yaitu benjolan di bawah kulit dan kadang di bawah lapisan konjungtiva. ${ }^{27}$ Kucing merupakan reservoir utama dari B. malayi di Thailand,cacing ini merupakan salah satu penyebab utama filariasis pada manusia. ${ }^{28}$

\section{KESIMPULAN}

Kabupaten Kuantan Singingi dan Pelalawan sudah tidak menjadi daerah endemis filariasis karena hasil SDJ menunjukkan Mfrate $<1 \%$, sedangkan Kabupaten Bangka Barat dan
Belitung masih menjadi daerah endemis karena ditemukan $M$ f rate $>1 \%$.

Reservoir filariasis B. malayi di Kabupaten Pelalawan adalah anjing dan kucing, sedangkan di Belitung adalah monyet ekor panjang.

\section{SARAN}

Perlu dilakukan POPM sekali per tahun selama 2 tahun di lokasi penelitian dengan melibatkan kader sebagai pengawas minum obat agar angka mikrofilaria tetap $<1 \%$ sehingga penularan filariasis dapat dicegah.Penularan masih dapat terjadi mengingat filariasis $B$. malayi merupakan penyakit zoonotik yang dapàt ditularkan dari hewan ke manusia atau sebaliknya.

\section{UCAPAN TERIMA KASIH}

Ucapan terima kasih penulis sampaikan kepada: Kepala Badan Litbangkes RI, Kepala Pusat UKM, Kepala Balai Litbangkes Baturaja, Kepala Dinas Kesehatan Provinsi Riau beserta staf, Kepala Dinas Kesehatan Provinsi Bangka Belitung beserta stafserta seluruh pihak yang telah berperan dalam kegiatan penelitian ini.

\section{DAFTAR PUSTAKA}

1. Meliyanie G, Andiarsa D. Program eliminasi lymphatic filariasis di Indonesia. JHECDs. 2018;3(2):63-70.

2. Kemenkes RI. Hasil Pre-TAS \& TAS 2016. Jakarta: Kemenkes RI; 2017.

3. Paniz-Mondolfi A, Gárate T, Stavropoulos C, Fan W, González LM, Mark E, et al. Zoonotic filariasis caused by Novel Brugia sp. Nematode, United States, 2011. Emerg Infect Dis. 2014;20(7):1248-50. https://wwwnc.cdc.gov/eid/article/20/7/pdfs/1 3-1654.pdf.

4. Kemenkes RI. Penentuan dan evaluasi daerah endemis filariasis dalam pedoman program eliminasi filariasis di Indonesia. Jakarta: Kementerian Kesehatan RI; 2012.

5. Suprapto A, Senewe FP, Irianti S, Anorital, Hananto M, Rachmawati F, et al. Studi evaluasi eliminasi filariasis di Indonesia Tahun 
2017 (studi multisenter filariasis). Jakarta; 2017.

6. WHO. Bench Aids for the diagnosis of filarial infection. Genewa: WHO;1997.

7. Shodiana. Study epidemiologi tentang malaria pada pekerja tambang timah tradisional di Kabupaten Bangka, Propinsi Kepulauan Bangka Belitung, Indonesia. pustaka.unpad.ac.id.

http://pustaka.unpad.ac.id/wpcontent/uploads/2013/11/Artikel-Cisral-

Shodiana-S2-IKM-Unpad.pdf. Published 2013. Accessed September 20, 2019.

8. R.E.S Roy Nusa. Prevalensi dan keberadaan vektor malaria di Desa Teluk Limau Kecamatan Jebus Kabupaten Bangka Barat, Provinsi Bangka Belitung. Aspirator. 2012;4(1):14-20.

9. Santoso. Periodisitas parasit filariasis di Desa Karya Makmur Kecamatan Lubuk Rajam, Kabupaten Ogan Komering Ulu Timur pada Tahun 2007. J Ekol Kesehat. 2010;9(1):117883.

10. Yahya, Santoso. Studi endemisitas filariasis di wilayah Kecamatan Pemayung, Kabupaten Batanghari pasca pengobatan massal tahap III. Bul Penelit Kesehat. 2013;41(1):18-25.

11. Ridha MR, Fakhrizal D. Periodisitas non periodik brugia malayi di Kabupaten Tabalong. Vektora. 2017;5(2):79-86.

12. WHO. Lymphatic filariasis. Clinical manifestations.

http://www.who.int/lymphatic_filariasis/epide miology/epidemiology_manifestations/en/. Published 2017. Accessed June 6, 2018.

13. Santoso, Cahyaningrum S. Re-Transmission assessment survey filariasis pasca pengobatan massal di Kabupaten Agam, Provinsi Sumatera Barat Tahun 2016. BALABA. 2017; 13(2):143-52.

14. Santoso, Yenni A, Oktarina R, Wurisastuti T. Efektivitas pengobatan massal filariasis tahap II menggunakan kombinasi DEC dengan Albendazole terhadap prevalensi Brugia malayi. Bul Penelit Sist Kesehat. 2015;41(2):161-68.

15. WHO. Monitoring and epidemiological assessment filariasis. [Internet]. http://whqlibdoc.who.int/hq/2005/who_cds_c pe_cee_2005.50.pdf. Accessed March 11,
2015.

16. Suryaningtyas NH, Arisanti M, Satriani AV, Inzana N, Santoso, Suhardi. Kondisi masyarakat pada masa surveilans pascatransmission assessment survey (TAS)-2 menuju eliminasi filariasis di Kabupaten Bangka Barat, Bangka Belitung. Bull Heal Res. 2018;46(1):35-44. http://dx.doi.org/10.22435/bpk.v46i1.7454.35 -44 .

17. Harrington H, Asugeni J, Jimuru C, Gwalaa J, Ribeyro E, Bradbury R, et al. A practical strategy for responding to a case of lymphatic filariasis post-elimination in Pacific Islands. Parasite \& Vectors. 2013;6(218):1-7.

18. Oktarina R, Santoso, Taviv Y, Gambaran angka prevalensi mikrofilaria di Kabupaten Banyuasin pasca pengobatan massal tahap III. BALABA. 2017;13(1):11-20.

19. Nurjana MA, Chadijah S, Veridiana NN, Anastasia H. Situasi filariasis setelah pengobatan massal tahun ketiga di Kabupaten Mamuju Utara. J Ekol Kesehat. 2017;16(2):93103.

20. Supriyono, Suriyani Tan S, Hadi UK. Perilaku nyamuk mansonia dan potensi reservoar dalam penularan filariasis di Desa Gulinggang Kabupaten Balangan Provinsi Kalimantan Selatan. Aspirator. 2017;9(1):1-10.

21. Kamil T. Studi biologis dan potensi vektor alami dirofilaria immitis sebagai landasan penyiapan bahan hayati. [Tesis] Fakultas Kedokteran Hewan IPB; 2002.

22. Edyansyah E. Epidemiologi filariasis di Desa Muara Padang Kecamatan Muara Padang Kabupaten Banyuasin Sumatera Selatan. [Tesis] Ilmu Kedokteran Dasar dan Biomedis UGM; 2011.

23. Edyansyah E, Wijaya Y. Hospes reservoir dan suspek vektor filariasis di Desa Muara Padang, Kabupaten Banyuasin, Sumatera Selatan. J Vektor Penyakit. 2012;VI(2):7-13.

24. Assady M, Nazarudin, Aliza D, Hamdani, Aisyah S, Rosmaidar. Prevalensi dirofilariasis pada anjing lokal (Canis domestica) di Kecamatan Lhoknga Aceh Besar secara patologi anatomis. J Med Vet. 2016;10(2):10911 .

25. Gunathilaka N, Shirom S, Lakmini W, Gayana G, Nilanga P. Subcutaneous dirofilariasis 
caused by Dirofilaria (Nochtiella) repens in Sri Lanka: A potential risk of transmitting human dirofilariasis. SAGE Open Med Case Reports. 2017;5:1-4. doi:10.1177/2050313X17701373.

26. Erawan I, Ida T, Wisnu N, Widaya A. Produksi antibodi anti - dirofilaria immitis untuk pengembangan diagnosis dirofilariasis pada anjing. Bul Vet Udayana. 2016;8(2):112-16.

27. Simon F, Javier G, Alicia D, Paula J, Rodrigo M, Vladimir K. The complexitiy of zoonotic filariasis episystem and its consequences: A multidisciplinary view. Hindawi BioMed Res Int. 2017;17(10). http://doi.org/10.1155/2017/6436130.

28. Wongkamchai S, Nuntiya M, Pakpimom M, Piyanan T, Sumat L, Supom F. Rapid detection and identification of Brugia malayi, B.pahangi, and Dirofilariasis immitis by high-resolution melting assay. Vector-Borne Zoonotic Dis. 2013;31(1):31-6. doi:10.1089/vbz.2012.0971.

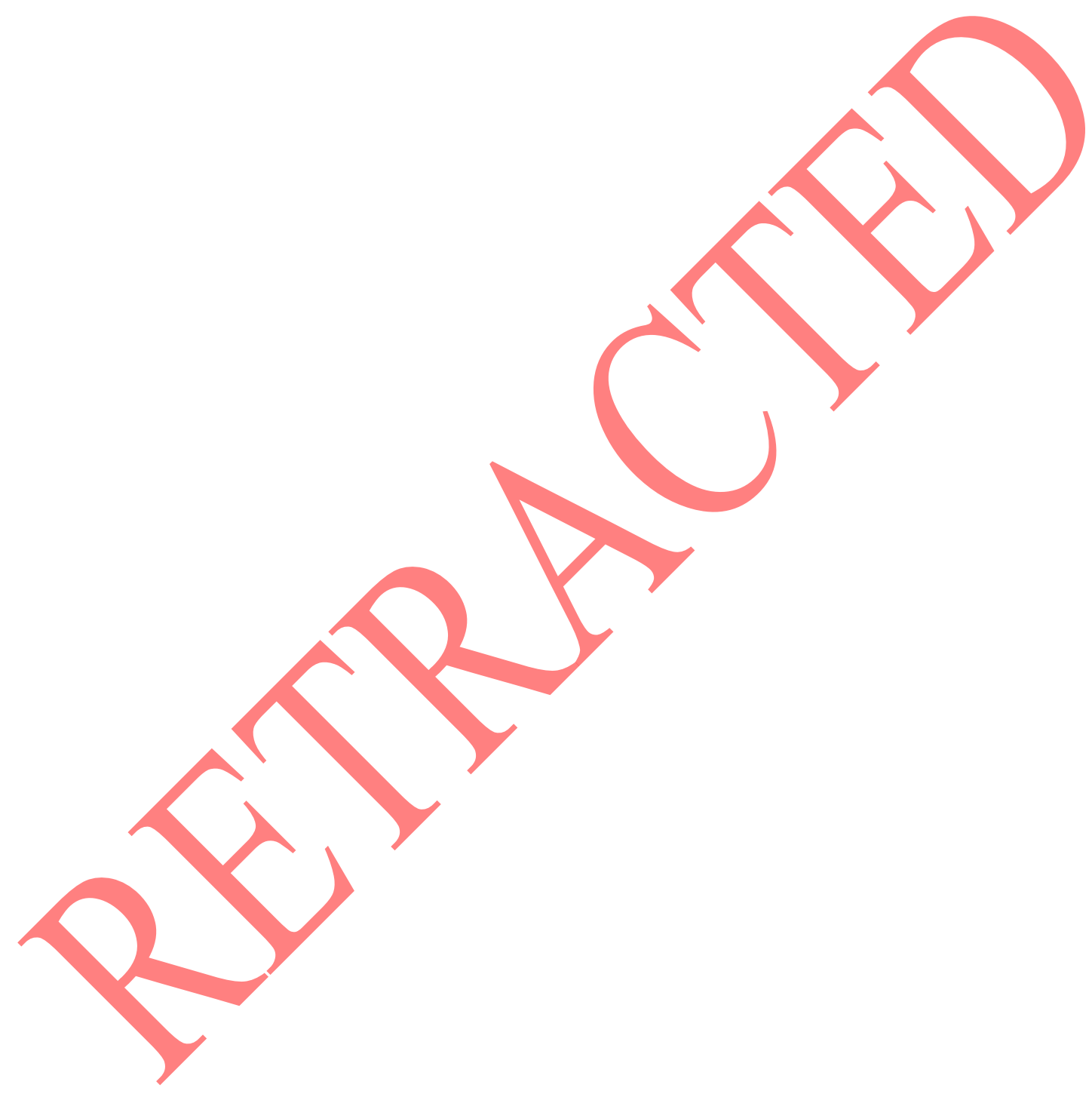

